\title{
Effects of Social Capital on Credit Access of Farming Households in Vietnam
}

\author{
NGUYẼ̃N TRỌNG HOÀI \\ University of Economics HCMC - hoaianh@ueh.edu.vn \\ TRẦ QUANG BẢO
}

Vung Tau Imex Garment Joint Stock Company - tqb1977@yahoo.com

ARTICLE INFO

Article history:

Received:

July 8, 2013

Received in revised form

Nov. 12, 2013

Accepted:

March 31, 2014

Keywords:

social capital, formal credit, semi-formal credit, informal credit, binary logistic regression, multinomial

logistic regression.

\section{ABSTRACT}

Social capital is considered as an influential factor in economic transactions, including credit access. The research aims at testing relationships between components of social capital and credit access in Vietnam's rural areas. The testing is conducted with binary logistic and multinomial logistic regression models. The results show that formal social network reduces possibility of getting access to formal credit, and households with wider formal social networks are likelier to belong to the group with access to semi-formal credit than the group with access to formal credit. Such conflicting results may come from specific characteristics of credit market in Vietnam's rural areas. 


\section{INTRODUCTION}

Social capital (SC) refers to "the mutual relations, interactions, and networks that emerge among human groups" (Wall et al., 1998). Researchers have discovered impacts of social networks on economic behaviors from different aspects. Presence of social networks increases farmers' ability to apply new techniques (Munshi, 2004; Conley \& Udry, 2008). According to Gomez \& Santor (2001), to self-employed small-size businesses, higher levels of social network may lead to higher income. Munshi (2003) shows that social networks may reduce job searching cost, thereby lowering information asymmetry that affects individuals in the labor market.

Regarding rural financial market, many researches, especially in developing countries, such as ones by Okten \& Osili (2004), Heikkilä et al. (2009), Wydick et al. (2011), Lawal et al. (2009), and Laszlo \& Santor (2009), prove the increasingly important role of the SC in credit access by families.

This research tries to confirm the role of SC in households' credit access, and provide empirical evidence of a problem with rural credit market in Vietnam that has not been studied closely. Additionally, the results also lead to certain policy implications and directions concerning the credit access for farming households, especially in depressed areas. Correct evaluation of the SC as an asset may pave the way to effective use of this capital source as an alternative mean for physical capital in economic transactions.

\section{THEORETICAL BASES AND ANALYTICAL FRAMEWORK}

Researchers examine the SC from various aspects: sociological (Coleman, 1988), political (Putnam, 1993) or economic views (Woolcock, 1998, 2001; Narayan, 1999; Fukuyama, 2001; and Stone et al., 2003). Nevertheless, it is agreed that this concept refers to "the mutual relations, interactions, and networks that emerge among human groups" as Wall et al. (1998) put it.

Researchers agree that the SC is a multi-dimensional concept, emphasizing both quality and structure of social relations. Both network structure and quality of relations are considered influential factors in different outcomes. Coleman (1998) argues that SC constitutes some special resource for an individual and comprises various entities. These entities have two elements in common: (1) including some aspect of social structure; and (2) facilitating certain actions of individuals. In his opinion, forms of SC comprise obligations and expectations, information channel and norms. 
Putnam et al. (1993) define SC as "features of social organization, such as trust, norms, and networks that can improve the efficiency of society by facilitating coordinated actions." According to these authors, social connections generate trust among individuals and groups. Social relations, in their turn, shape mutual obligations within communities and make community members behave according to reciprocal norms in which individuals help others without expecting anything in return. Thus, trust, networks, and reciprocal norms are important elements of community SC.

Putnam (2000) as cited by Sen (2010) divides social networks into two groups: (1) formal social connections where individuals take part in legal organizations, such as political, religious or professional organizations; and (2) informal social connections, e.g., participation with neighbors, friends, coworkers and even strangers. In his works, Putnam considers trust as central to theory of SC. Trust is an essential element of SC (Putnam et al., 1993). The trust creates favorable condition for cooperation, and the greater the trustworthiness within a community, the greater the cooperation.

Other authors examine the SC according to features of social relations and networks. In their view, SC is divided into three types: bonding, bridging and linking SC (Narayan, 1999; and Woolcock, 2000, as cited by Stone et al., 2003). Bonding SC exists in close or intimate networks such as families, neighbors and friends; bridging social network refers to overlapping links common among coworkers or partners; and linking SC indicates social relations with persons in administrative machinery or organizations.

Research team of the World Bank (2011) argues that SC referring to norms and networks that induce collective actions include five principal components: groups and networks, trust and solidarity, collective action and cooperation, social cohesion and inclusion, and information and communication. SC comprises not only organizations in a community but also the glue linking them together.

Different views produce different measures of SC. By combining qualitative and quantitative methods, many researchers could suggest useful measures or proxy variables for measuring the SC (Woolcock \& Narayan, 2000). Proxies were used broadly in researches by Coleman (1988) and Putnam (1995) for measuring the SC. Several recent studies have also used questionnaires along with proxies for this purpose, especially those developed by Onyx \& Bullen (2000) and World Bank (2011). Grootaert (1998) mentions many indicators to measure the SC used by quantitative researches. 
Indicators used for measuring SC should reflect two basic features of SC: structural characteristics of networks and quality of relationships.

The role of social network in alleviation of information asymmetry or reduction in job searching cost is discussed widely in literature on the role of SC in the economy. Influential researches by Putnam et al. (1993) and Glaeser et al. (1999) establish the argument that social networks play important roles in economic transactions. Researchers detect impacts of social networks on different economic activities, such as encouraging farmers to apply new techniques, increasing revenue for businesses or reducing job searching costs.

Concerning credit market in rural areas, many researches have demonstrated the increasingly important role of SC in household credit access. Okten \& Osili (2004) find that both family and community networks produce positive effects on activities related to credit access: getting aware of credit sources, making decision to apply for loans, and securing loans. According to Togba (2009), trust in microfinancial structure and ability to engage in microcredit programs by households correlate when lack of trust reduces ability to select microfinance organizations. Analyses by Hoang et al. (2010) show that bonding and bridging SC produce no effect on credit obligations while linking SC may reduce such obligations among households in Vietnam's rural areas.

Research by Guiso et al. (2004) on relationship between SC and financial development shows that SC has a negative relationship with the probability of not having access to credit; and in informal credit market, a fall of one percentage point in standard deviation of SC makes the ability to secure an informal loan increase by $1 \%$. Findings by Heikkilä et al. (2009) show that in selecting types of financial institutions (formal, semi-formal and informal ones), personal SC has a positive relationship to ability to secure loans from semi-formal and informal financial institutions; and moreover, borrower's social connections are more significant to informal organizations than formal ones.

Wydick et al. (2011) discover that church networks play an outstanding role in determining sources of credit of households. For every class of credit, "if the percentage of people accessing microfinance in a church network doubles, the probability of an individual household is accessing microfinance increases by 14.1 percent."

In sum, aforementioned theories and empirical researches serve as a basis for our analytical framework presented in Figure 1. 


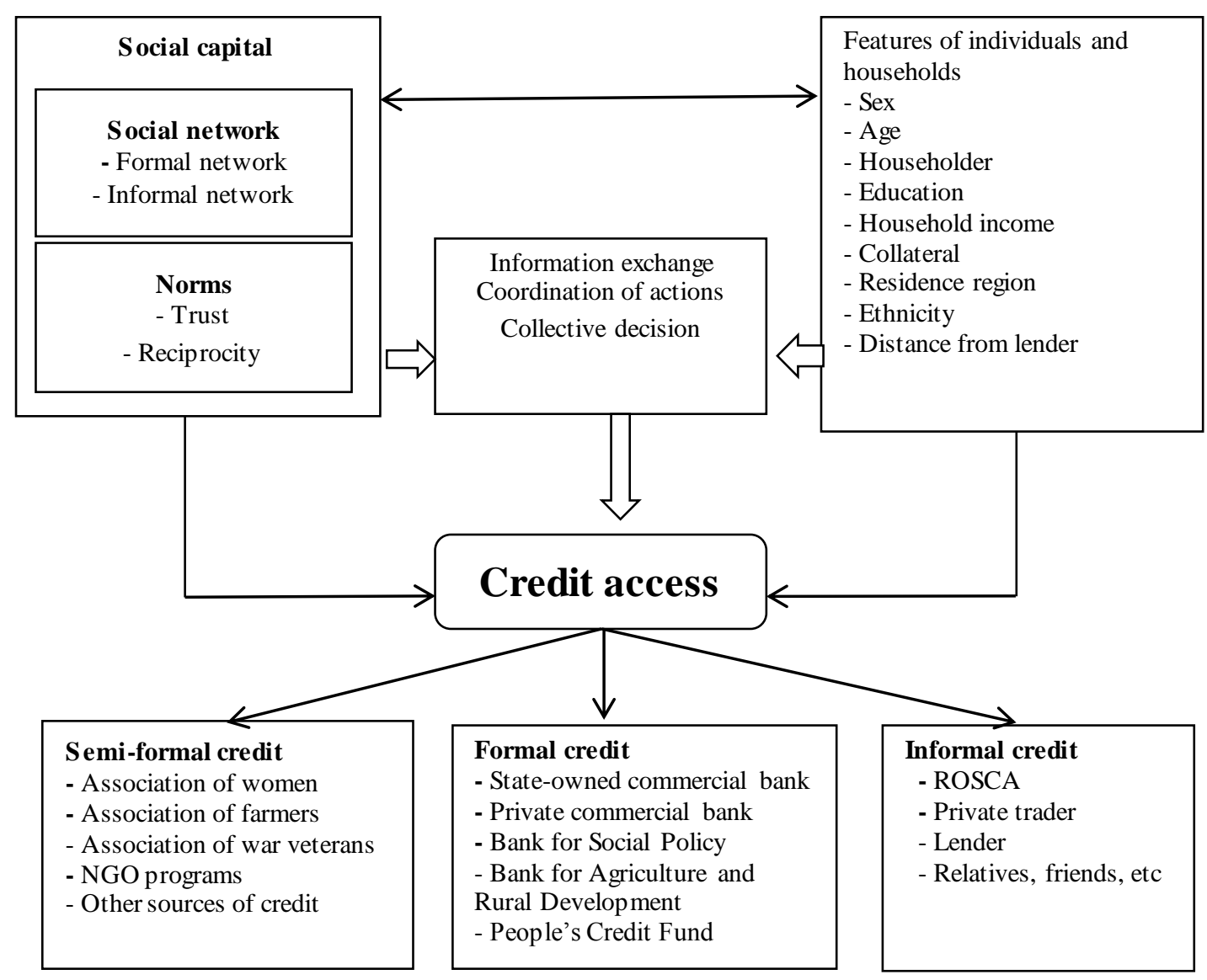

\section{Figure 1: Relationship between Social Capital and Credit Access}

Source: Designed by authors based on literature review

\section{METHODOLOGY}

\section{a. Model:}

Researches on credit access of Vietnamese rural households agree that formal credit sector accounts for the biggest shares in both supply and demand sides in rural credit market (Lensink et al., 2008; Hà Hoàng Hợp et al., n.d.). This research, therefore, tries to develop a model examining impacts of SC on formal credit access. Additionally, it also pays proper attention to the role of SC in access to other types of credit. A second model is therefore developed to assess impacts of SC on access to credit in all three sectors: formal, informal and semi-formal ones. 
In each model, the role of SC is examined through three indexes: two indexes concerning structural features of networks (informal and formal networks) and one referring to trust as quality of the network. Regarding features of individuals and households, the research examines the following elements: gender, age, householder, education, household income, collateral, residence region, ethnicity, and distance from lender. The model for analysis is presented in Figure 2.

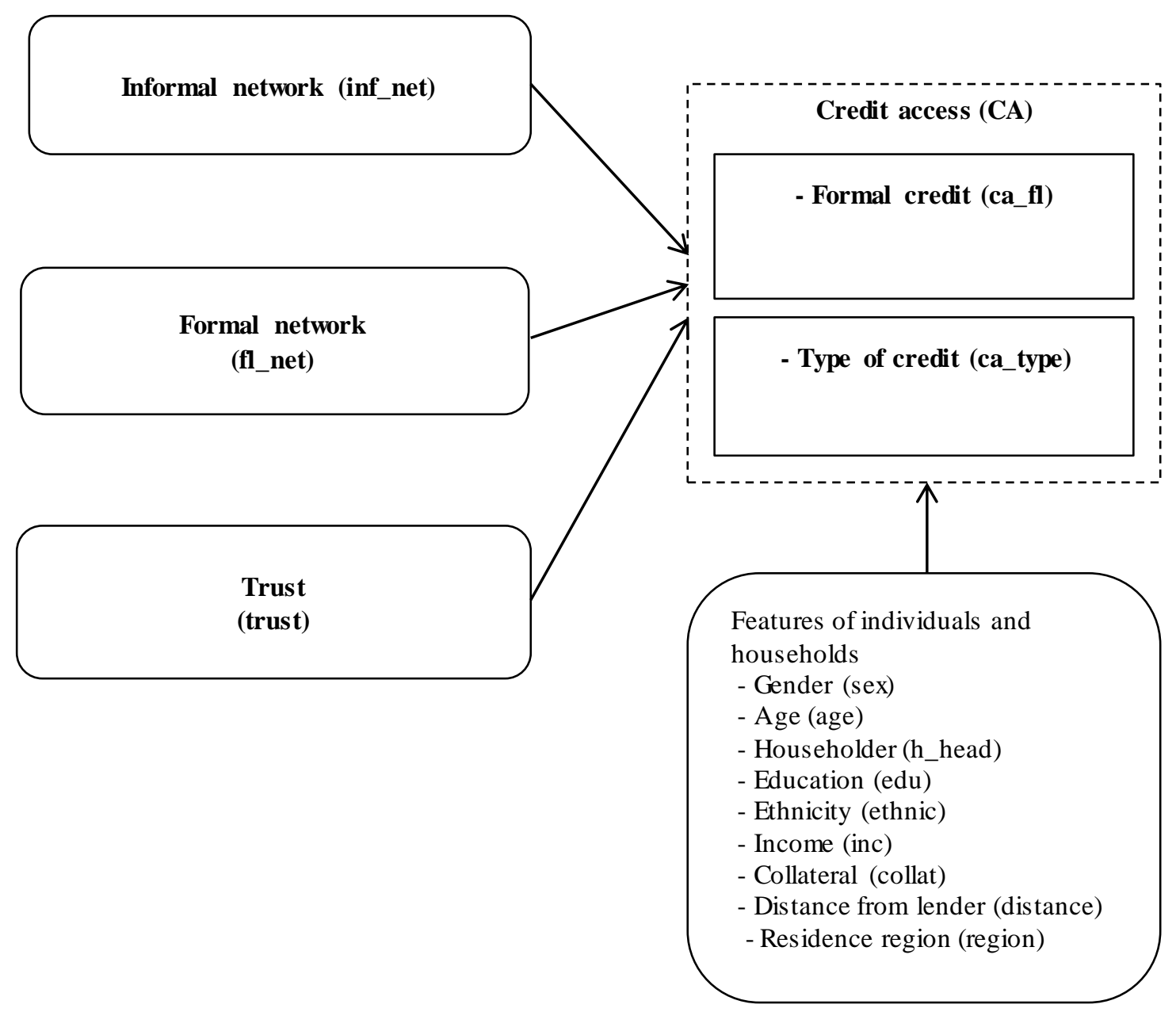

Figure 2: Model for Analysis

\section{b. Data and Sample:}

The research employs secondary data from the Vietnam Access to Resources Household Survey (VARHS) conducted by Institute of Labor Science and Social Affairs 
under Ministry of Labor, Invalids and Social Affairs in cooperation with several scientific organizations. The research employs the dataset VARHS 2008 because the newer dataset is not accessible. The 2008 dataset, however, is acceptable because SC and credit access experience very little change over time.

VARHS 2008 examines over 3,000 households in 12 provinces over various aspects and therefore serves well this research. Firstly, it provides a panoramic view on two subject matters of our research: (1) information about credit access by households is gathered and presented in detail, including loan size, interest, and sources (formal and informal), etc.; and (2) SC is expressed in various factors, such as groups, networks, trust and cooperation, and political relationship. Secondly, the dataset is reliable because it is a result of a comprehensive survey conducted jointly by a group of local and foreign scientific organizations: Central Institute for Economic Management (CIEM), Institute of Policy and Strategy for Agriculture and Rural Development (IPSARD), Institute of Labor Science and Social Affairs (ILSSA), and Department of Economics of University of Copenhagen.

From this dataset, authors develop a sample comprising only matters related to the research. Specifically, the sample includes data on households with access to credit sources in six provinces typical of six regions of Vietnam, as shown in Table 1.

Table 1: Provinces Included in the Research

\begin{tabular}{lll}
\hline \multicolumn{1}{c}{ Province } & \multicolumn{1}{c}{ Region } & Household \\
\hline Lào Cai & Midlands and mountainous region in the North & 114 \\
(former) Hà Tây & Hồng River Delta & 209 \\
Nghệ An & Northern Central Vietnam & 80 \\
Đắk Lắk & Western Highlands & 193 \\
Quảng Nam & Coastal Central Vietnam & 112 \\
Long An & Mekong Delta & 151 \\
\hline Total & & 859 \\
\hline
\end{tabular}

Source: selected from VARHS 2008

These provinces are chosen because they are best representative of other provinces with the highest number of surveyed households and typical of lifestyle and socioeconomic conditions of their region; and they offer credit access widely to their 
population. After extracting necessary data and removing inappropriate ones, the final sample comprises 859 households.

\section{c. Data Processing:}

Two regression models are used for assessing impacts of independent variables on dependent one.

- In the binary logistic model, dependent variable ca_fl equals 1 if the household can get access to formal credit and 0 otherwise.

- In the multinomial logistic model value of dependent variable ca_type equals 1 if the household can get access to formal credit, 2 if it accesses semi-formal credit and 3 if it uses informal credit sources.

\section{RESULTS AND DISCUSSION}

\section{a. Social Capital and Access to Formal Credit:}

Table 2 presents results from the binary logistic regression model. Test values show that a strong relationship exists between the dependent variable and the set of explanatory variables with Chi-square equaling $422.517(\mathrm{p}=0.000)$, Nagelkerke Pseudo$\mathrm{R}^{2}$ equaling 0.521 and predictive power of the model equaling $77.2 \%$.

Of three components of the SC, however, only formal social network has a statistically significant impact on the dependent variable at $p \leq 0.05$. Coefficient of this variable is -0.2 , which implies that the formal social network had a negative relationship with ability to get formal credit access. Assume that initial probability of formal credit access is $10 \%$, and all other factors are held constant, a $1 \%$ increase in the household's formal social network make the probability of formal credit access fall by 1.66 percentage points to $8.34 \%$

Apparently, this finding did not support theory of the role of formal network in access to formal credit from banks. This can be explained as follows: most civic organizations where farmers take part in, such as association of women and association of farmers have their own funds for credit services (Hà Hoàng Hợp et al., n.d.), and their prioritized customers are their own members. In other words, supply of credit for households is usually from such organizations rather than from commercial banks. Two remaining components, informal network and trust also have effects on formal credit access but they are not statistically significant. 
Apparently, unlike such researches on relationship between SC and credit access in developing countries such as Okten \& Osili (2004) and Dufhues et al. (2012), these results are surprising, but these conflicting findings can be explained by flexibility of credit market in Vietnam's rural areas.

Within poverty alleviation and hunger eradication policy, programs to supply credit to the poor are carried out all over rural districts by Vietnam Bank for Social Policy and Bank for Agriculture and Rural Development. Information about loans with preferential interest rate is transmitted to rural households through mass media and local authorities. Thus, mechanism for disseminating and employing information about participation in an organization is not important to the formal credit market.

In this research, the supply of information by the formal social network does not affect the possibility of formal credit access. Moreover, support from authorities also facilitates the supply of loans by related banks. Handling cost, or expenses on supervision and investigation of customers' creditworthiness in these banks may be very small, and therefore the banks need not protect themselves by setting limits on loans for customers of whom they do not have full information. This implies that when supplying loans, banks do not pay much attention to trustworthiness of a community.

Table 2: Binary Logistic Regression $(\mathrm{N}=859)$

\begin{tabular}{|c|c|c|c|}
\hline Independent variables & $\begin{array}{c}\beta \\
(\mathrm{SE})\end{array}$ & Wald & $\operatorname{Exp}(\beta)$ \\
\hline Formal network & $\begin{array}{c}-0.200^{* *} \\
(0.097)\end{array}$ & 4.217 & 0.819 \\
\hline Informal network & $\begin{array}{l}-0.005 \\
(0.017)\end{array}$ & 0.089 & 0.995 \\
\hline Trust & $\begin{array}{l}-0.019 \\
(0.153)\end{array}$ & 0.015 & 0.981 \\
\hline Householder & $\begin{array}{c}0.081 \\
(0.271)\end{array}$ & 0.088 & 1.084 \\
\hline Gender & $\begin{array}{c}0.375 \\
(0.253)\end{array}$ & 2.194 & 1.455 \\
\hline Age & $\begin{array}{c}0.071 \\
(0.045)\end{array}$ & 2.462 & 1.074 \\
\hline
\end{tabular}




\begin{tabular}{|c|c|c|c|}
\hline$(A g e)^{2}$ & $\begin{array}{c}0.000 \\
(0.000)\end{array}$ & 2.327 & 0.999 \\
\hline Education & $\begin{array}{c}0.038 \\
(0.030)\end{array}$ & 1.577 & 1.039 \\
\hline Ethnicity & $\begin{array}{c}-0.854^{* * *} \\
(0.239)\end{array}$ & 12.767 & 0.426 \\
\hline Collateral & $\begin{array}{c}4.508^{* * *} \\
(0.385)\end{array}$ & 137.400 & 90.708 \\
\hline Household income & $\begin{array}{c}0.000 \\
(0.000)\end{array}$ & 0.004 & 1.000 \\
\hline Distance & $\begin{array}{c}0.001 \\
(0.003)\end{array}$ & 0.165 & 0.999 \\
\hline$\chi^{2}$ & & 422.517 & \\
\hline Degree offreedom & & 12 & \\
\hline p-value & & 0.000 & \\
\hline Nagelkerke Pseudo- $R^{2}$ & & 0.521 & \\
\hline -2Log Likelihood & & 754.947 & \\
\hline Exactly predictive power & & $77.2 \%$ & \\
\hline
\end{tabular}

Notes: Estimate of the binary logistic regression - Dependent variable: Possibility of formal credit access (ca_fl), variable region is undercontrol. Standard deviation is in brackets. ***,** and * denote significance levels of $1 \%, 5 \%$ and $10 \%$ respectively

Source: Estimates based on the sample taken from VARHS 2008 data.

\section{b. Social Capital and Access to Different Types of Credit:}

Table 3 presents results from analysis with the binary logistic regression model. Test values show that a strong relationship exists between the dependent variable and the set of explanatory variables with Chi-square equaling $464.384(\mathrm{p}=0.000)$, Nagelkerke Pseudo- $\mathrm{R}^{2}$ equaling 0.493 and predictive power of the model equaling $67.5 \%$.

Three components of the SC produce effects on the choice of semi-formal credit instead of formal one in different degrees and directions, but only formal social network is statistically significant at $1 \%$. Coefficient of this variable is 0.397 and $\operatorname{Exp}(\beta)$ equals 1.487, which implies that surveyed households with broader formal social network are 
likely to belong to the group with access to semi-formal credit than the group with access to formal credit. Assuming that initial probability of semi-formal credit access is $10 \%$, and all other factors are held constant, a $1 \%$ increase in the household's formal social network causes the probability of semi-formal credit access to increase by 4.18 percentage points to $14.18 \%$.

This finding implies that operations of SC are significant to the credit market, and especially the semi-formal one, in Vietnam's rural areas. Meanwhile, relative comparison between the group with informal credit access and the one with formal credit access shows that all three components of SC produce some effects but regression coefficients of these variables are not statistically significant.

Table 3: Multinomial Logistic Regression $(\mathbf{N}=\mathbf{8 5 9})$

\begin{tabular}{|c|c|c|c|c|c|c|}
\hline \multirow{2}{*}{$\begin{array}{c}\text { Independent } \\
\text { variables }\end{array}$} & \multicolumn{3}{|c|}{ Semi-formal credit access } & \multicolumn{3}{|c|}{ Informal credit access } \\
\hline & $\begin{array}{c}\beta \\
(\mathrm{SE})\end{array}$ & Wald & $\operatorname{Exp}(\beta)$ & $\begin{array}{c}\beta \\
(\mathbf{S E})\end{array}$ & Wald & $\operatorname{Exp}(\beta)$ \\
\hline Formal network & $\begin{array}{c}0.397^{* * * *} \\
(0.134)\end{array}$ & 8.719 & 1.487 & $\begin{array}{c}0.121 \\
(0.104)\end{array}$ & 1.349 & 1.129 \\
\hline Informal network & $\begin{array}{l}-0.009 \\
(0.024)\end{array}$ & 0.146 & 0.991 & $\begin{array}{c}0.012 \\
(0.018)\end{array}$ & 0.438 & 1.012 \\
\hline Trust & $\begin{array}{c}0.292 \\
(0.239)\end{array}$ & 1.496 & 1.339 & $\begin{array}{l}-0.085 \\
(0.162)\end{array}$ & 0.276 & 0.918 \\
\hline Householder & $\begin{array}{c}0.350 \\
(0.359)\end{array}$ & 0.950 & 1.420 & $\begin{array}{l}-0.057 \\
(0.291)\end{array}$ & 0.038 & 0.945 \\
\hline Gender & $\begin{array}{l}0.768^{* *} \\
(0.340)\end{array}$ & 5.119 & 2.156 & $\begin{array}{c}0.200 \\
(0.272)\end{array}$ & 0.542 & 1.222 \\
\hline Age & $\begin{array}{c}0.083 \\
(0.077)\end{array}$ & 1.163 & 1.087 & $\begin{array}{c}-0.121^{* *} \\
(0.048)\end{array}$ & 6.462 & 0.886 \\
\hline$(A g e)^{2}$ & $\begin{array}{c}0.000 \\
(0.001)\end{array}$ & 0.978 & 0.999 & $\begin{array}{l}0.001^{\text {** }} \\
(0.000)\end{array}$ & 6.043 & 1.001 \\
\hline Education & $\begin{array}{c}0.017 \\
(0.043)\end{array}$ & 0.158 & 1.017 & $\begin{array}{l}-0.062^{*} \\
(0.033)\end{array}$ & 3.614 & 0.940 \\
\hline Ethnicity & $\begin{array}{l}-0.271 \\
(0.330)\end{array}$ & 0.676 & 0.763 & $\begin{array}{c}-1.106^{* * *} \\
(0.262)\end{array}$ & 17.797 & 0.331 \\
\hline
\end{tabular}




\begin{tabular}{|c|c|c|c|c|c|c|}
\hline Collateral & $\begin{array}{l}3.450^{* * *} \\
(0.485)\end{array}$ & 50.606 & 31.488 & $\begin{array}{l}5.310^{* * *} \\
(0.661)\end{array}$ & 75.508 & 202.384 \\
\hline Household income & $\begin{array}{c}0.000 \\
(0.000)\end{array}$ & 0.153 & 1.000 & $\begin{array}{c}0.000 \\
(0.000)\end{array}$ & 0.130 & 1.000 \\
\hline Distance & $\begin{array}{l}-0.015 \\
(0.011)\end{array}$ & 1.687 & 0.985 & $\begin{array}{c}0.003 \\
(0.003)\end{array}$ & 0.704 & 1.003 \\
\hline$\chi^{2}$ & \multicolumn{6}{|c|}{464.384} \\
\hline Degree offreedom & \multicolumn{6}{|c|}{24} \\
\hline$p$-value & \multicolumn{6}{|c|}{0.000} \\
\hline Nagelkerke & \multicolumn{6}{|c|}{0.493} \\
\hline \multicolumn{7}{|l|}{ Pseudo-R ${ }^{2}$} \\
\hline -2Log Likelihood & \multicolumn{6}{|c|}{1148.636} \\
\hline $\begin{array}{l}\text { Exactly predictive } \\
\text { power }\end{array}$ & \multicolumn{6}{|c|}{$67.5 \%$} \\
\hline
\end{tabular}

Notes: Estimate of the multinomial logistic regression - Dependent variable Possibility of access to different types of credit (ca_type) equals 1 if the household can get access to formal credit, 2 if it accesses semi-formal credit and 3 if it uses informal credit sources; variable region is under control. Reference category in all models is the possibility of formal credit access. Standard deviation is in brackets. $* * * * *$ and $*$ denote significance levels of $1 \%, 5 \%$ and $10 \%$ respectively

Source: Estimates based on the sample taken from VARHS 2008 data.

\section{c. Demographic Characteristics and Credit Access:}

When examining the comparative relationship between semi-formal and formal credit, it is not surprising to find that collateral is statistically significant at $1 \%$. Apparently, collateral is the highest barrier to the formal credit sector. Semi-formal credit supplier may require no collateral; households with valuable assets tend to get loans from banks because banks can provide big loans and pay less attention to customers' creditworthiness than semi-formal credit suppliers. This behavior is appropriate to the credit market in rural areas and compliant with conclusion by Lensink et al. (2008) that male customers prefer formal credit sources while female ones tend to rely on less formal sources.

Unlike the comparative relationship between groups with semi-formal credit access and group with formal one, results of relative comparison between group with informal 
credit access and group with formal one show that many factors produce statistically significant effects. Collateral is still an important factor affecting the choice between those two sources of credit.

Unlike semi-formal credit supplying organizations, most suppliers of informal credit in Vietnam's rural areas usually resort to malpractices. As a result, households with assets that can be used as collateral never choose this source of credit.

Besides collateral, borrowers' education, ethnicity and age also affect their choice between the two sources of credit. Simple organizations and procedures of semi-formal credit sector are certainly suitable for borrowers of low education while more educated persons prefer commercial banks.

It is noteworthy that households of ethnic minorities are likely to belong to the group employing formal credit sources. In ethnic minorities, there is no condition for development of informal credit services, so households go to banks when in needs.

Regarding borrowers' age, old borrowers prefer the formal credit to other type because they may understand malpractices and risks in the informal credit sector. Statistically significant coefficient of variable (Age) ${ }^{2}$ implies that to a certain age borrowers tend to move from the group with formal credit access to the group with informal credit access. This finding is compliant with the hypothesis and past researches. Old age is a barrier to the formal credit sector where many procedures exist while the mind of old people is waned. It is surprising that household income has no effect on the choice of types of credit sources, and distance from lender has only a slight and statistically insignificant impact.

\section{CONCLUSION AND POLICY IMPLICATIONS}

\section{a. Conclusion:}

This research examines the role of SC in credit access by rural households, a less discussed topic in Vietnam. Employing a sample of 859 households in six provinces (Đắk Lắk, Hà Tây, Lào Cai, Long An, Nghệ An and Quảng Nam) based on the dataset of 2008 VARHS and suitable regression models (binary logistic and multinomial logistic ones), the research finds that among three components of SC (formal social network, informal social network and trust) used for measuring impacts on credit access, only formal social network has a statistically significant effects. 
Of eight traditional factors included in both regression models, collateral has the strongest impact on formal credit access. Additionally, factor ethnicity shows that households of ethnic minorities are more likely to seek formal credit access than Kinh households; gender shows that female borrowers tend to prefer semi-formal credit source; education implies that borrower with higher educational level usually choose formal credit sources while age also drives mature borrowers to formal credit sector. It is noteworthy that household income has no impact on credit access in any case and distance has a slight impact in various directions. This impact, however, is not statistically significant.

\section{b. Policy Implications :}

Theories of SC conclude that SC is a valuable asset that help owner deal with barriers and achieve their goals. In many cases, SC can replace physical capital, especially in rural districts with low personal income in such a developing country as Vietnam. Findings of this research demonstrate the role of SC, or formal social network to be precise, in the credit market in rural areas. This impact is apparent in the semi-formal credit market.

However, the demand for credit in rural areas is great and most households are badly in need of credits. Dealing with this problem required a joint effort by households, banking institutions and government. The research suggests the following measures:

- Improving social capital: Households can improve their SC by joining civic organizations and actively taking part in community activities in order to build trust among community members. Additionally, education may be the factor that creates the biggest SC. Education institutions not only provide learners with human capital but also disseminate SC in the form of rules and social norms (Fukuyama, 2001). Households, therefore, should pay full attention to education and ensure good education for their children. The government should supply this service at low cost to rural areas.

- Diversifying financial services and formal credit: Not every household can take part in civic organizations that supply credit and financial services. And if all households can do so, semi-formal and informal credit suppliers can hardly satisfy the demand for credit in rural areas. The long-term and sustainable policy is to diversify financial services and formal credit and then extend credit access to every household. If this policy is implemented properly, social networks and trust can serve as links between households and suppliers of financial services and formal credit. 
- Increasing the supply of credit: Although the research finds that informal social network and trust are insignificant factors, authors see that operations of formal credit sector make those two factors less effective. The credit market in rural areas is mostly controlled by Bank for Social Policy and Bank for Agriculture and Rural Development. With support from the government, the two banks can supply credit to rural households and the question is to what extent they satisfy the demand for credit by rural households.

To achieve a sustainable development, it is necessary to expand and diversify sources of credit. The government should take measures to encourage all banking institutions to engage in this market, especially microcredit suppliers. In a more competitive and diverse market, factors acting as catalysts, including components of SC, will produce significant effects on economic transactions

\section{References}

Coleman, J. S. (1988), "Social Capital and the Creation of Human Capital", The American Journal of Sociology, Vol. 94, Supplement: Organizations and Institutions: Sociological and Economic Approaches to the Analysis of Social Structure, pp. S95-S120.

Conley, T. \& C. Udry (2008), "Learning about a New Technology: Pineapple in Ghana", American Economic Review, 100(1): 35-69.

Dufhues, T., G. Buchenrieder \& N. Munkung (2012), "Individual Social Capital and Access to Formal Credit in Thailand", Selected Paper prepared for presentation at the International Association of Agricultural Economists (IAAE) Triennial Conference, Foz do Iguacu, Brazil.

Fukuyama, F. (2001), "Social Capital, Civil Society and Development", Third World Quarterly, Vol. 22, No.1, pp. 7-20.

Gomez, R. \& E. Santor (2001), "Membership Has its Privileges: Social Capital, Neighborhood Characteristics and the Earnings of Micro-Finance Borrowers" Canadian Journal of Economics, Vol. 34, No. 4, pp. 943-66.

Grootaert, C. (1999), "Social Capital, Household Welfare and Poverty in Indonesia”, Local Level Institution Study Working Paper No. 6, Washington D. C., The World Bank.

Guiso, L., P. Sapienza \& L. Zingales (2004), "The Role of Social Capital in Financial Development”, American Economic Review, Vol. 94, No. 3, pp. 526-56.

Hà Hoàng Hợp, Nguyễn Minh Hương \& Ngô Thị Minh Hương (n.d), "Việt Nam sau khi gia nhập WTO: Tài chính vi mô và tiếp cận tín dụng của người nghèo ở nông thôn”, Report on a research for Centre for Development and Integration and Action Aid Vietnam. 
Heikkilä, A., P. Kalmi \& O.P. Ruuskanen (2009), "Social Capital and Access to Credit: Evidence from Uganda", Presentation at the World Bank Conference on Measurement, Promotion and Impact of Access to Financial Services.

Hoang, D.Q., T. Dufhues \& G. Buchenrieder (2010), "Social Capital and Credit Constraints: A Case Study from Vietnam", paper for presentation at the International Symposium on Sustainable Land Use and Rural Development in Mountainous Regions of Southeast Asia, Hanoi, 21-23 July 2010.

Laszlo, S. \& E. Santor (2009), "Migration, Social Networks and Credit: Empirical Evidence from Peru", The Developing Economies, Vol. 47, No. 4, pp. 383-409.

Lawal, J. O., B. T. Omonona, O. I. Y. Ajani \& O.A. Oni (2009), "Effects of Social Capital on Credit Access among Cocoa Farming Households in Osun State, Nigeria", Agricultural Journal, Vol. 4, No. 4, pp. 184-191.

Lensink, R., Nguyen, V. N. \& Le, K. N. (2008), “Determinants of Farming Households' Access to Formal Credit in the Mekong Delta, Vietnam", Final Report for NPT-Part B4-Paper 9.

Munshi, K. (2003), "Networks in the Modern Economy: Mexican Migrants in the Us Labor Market", Quarterly Journal of Economics, Vol. 118, No. 2, pp. 549-599.

Munshi, K. (2004), "Social Learning in a Heterogeneous Population: Technology Diffusion in the Indian Green Revolution”, Journal of Development Economics, Vol. 73, No. 1, pp. 185-213.

Okten, C. \& U. O. Osili (2004), "Social Networks and Credit Access in Indonesia" World Development, Vol. 32, No. 7, pp. 1225-1246.

Putnam, R. D. (1995), "Bowling Alone: America's Declining Social Capital", Journal of Democracy, Vol. 6, No. 1, pp. 65-78.

Putnam, R., D. with R. Leonardi \& R. Y. Nonetti (1993), Making Democracy Work: Civic Traditions in Modern Italy, Princeton: Princeton University Press.

Sen, U. (2010), Social Capital and Trust: The Relationship between Social Capital Factors and Trust in the Police in the United States (Ph. D Dissertation at the University of Texas), ProQuest.

Stone W., M. Gray \& J. Hughes (2003), "Social Capital at Work: How Family, Friends and Civic Ties Relate to Labor Market Outcomes", Research Paper No. 3, Australian Institute of Family Studies.

Togba, E. L. (2009), "Microfinance, Social Capital and Households Access to Credit: Evidence from Côte d'Ivoire", to be presented at the 7th international conference on "Inclusive Growth, Innovation and Technological Change: education, social capital and sustainable development", organized by GLOBELICS, 6-8 October 2009, Dakar (Senegal).

Wall, E., G. Ferazzi \& F. Schryer (1998), "Getting the Goods on Social Capital", Rural Sociology, Vol. 63, No. 2, pp. 300-322.

Woolcock, M. (1998), "Social Capital and Economic Development: Toward a Theoretical Synthesis and Policy Framework", Theory and Society, Vol. 27, No.2, pp. 151-208. 
Woolcock, M. (2001), "The Place of Social Capital in Understanding Social and Economic Outcomes”, ISUMA Canadian Journal of Policy Research, Vol. 2, No.1, pp. 11-17.

Woolcock, M. \& D. Narayan (2000), "Social Capital: Implications for Development Theory, Research, and Policy”, World Bank Research Observer, Vol. 15, No. 2, pp. 225-249.

World Bank, The (2011), "Social Capital Topics" available at http://go.worldbank.org/OEOSW08A20

Wydick, B., H. K. Hayes \& S. K. Kempf (2011), "Social Networks, Neighborhood Effects, and Credit Access: Evidence from Rural Guatemala”, World Development, Vol. 39, No. 6, pp. 974-982. 